J. Product. \& Dev., 24(2): 371 - 390 (2019)

\title{
EVALUATION OF HUANGLONGBING TOLERANCE IN CITRUS BREEDING POPULATIONS
}

\author{
A. Mira ${ }^{1,2}$; Q. Yu ${ }^{1}$;M. Mattia ${ }^{1}$;Y. Yu ${ }^{1}$; E. M. Mohammed ${ }^{2}$;A. A. El-Aidy ${ }^{2}$; \\ K. El-Abbasy ${ }^{2}$ and F. G. Gmitter Jr ${ }^{1 *}$. \\ 1 Department of Horticultural Sciences, IFAS, Citrus Research and Education \\ Center, University of Florida, Lake Alfred, Florida 33850, USA. \\ 2 Department of Horticulture, Faculty of Agriculture, Tanta University, Tanta, Egypt. \\ * Corresponding author: Amany Mira, E-mail: amanymira@agr.tanta.edu.eg
}

\section{ABSTRACT}

Huanglongbing (HLB) or greening disease is one of the most destructive disease of citrus industry all over the world. This disease had become widespread in Florida, USA since 2005. It is caused by a phloem limited bacterium called Candidatus Liberibacter asiaticus (CLas). Hybrids and populations produced by citrus breeding programs have likewise been ravaged by the disease. Thousands of unique genotypes have been exposed to natural CLas infection in the field for more than 10 years now, citrus researchers have had an opportunity to observe very substantial differences in the speed with which different types become affected by HLB, as well as the severity of symptoms. In the winter of 2015-16, we examined HLB responses in over 5000 citrus trees from hundreds of crosses made by the UF-CREC breeding program since 1986. The parentage of the crosses included pomelo, mandarin, sweet orange, grapefruit, trifoliate orange, and other miscellaneous citrus species. Ploidy levels in the populations included diploid, triploid and tetraploid. Depending on our field evaluation and symptoms of HLB disease on the trees, we divided all the trees to 5 categories according to the following ranking system ( $1=$ tolerant, $2=$ good looking, $3=$ medium, $4=$ bad, 5=dead). In total, only 5.3\% trees among all other categories showed a very healthy appearance and no symptoms for HLB that we characterized them as HLB tolerant trees. Crosses $\{($ Clementine $x$ Temple) $x$ C. ichangensis\} followed by \{(Clementine $x$ Temple) $x$ Swingle\} had most tolerant trees among all of them trees. By using qPCR to determine CLas titer in visual tolerant trees, we conducted that $48.7 \%$ were CLas-positive, which have CT value less than 32, while $47.3 \%$ were CLas-negative with CT value equals or more than 32, it means that 
some trees have the bacteria but still don't show any symptoms for the disease. The crosses [DPI 4-6 (Red Java) $x$ H.B, (Clementine X Minneola) X Chinotto, VB Temple X (Nova + Ortanique), VB Temple X (Nova + Succari), (Clementine X Temple) X c. ichangensis] present the best crosses because they have CT value $=40$, that means no CLas in those trees. On the other hand, some characters of this category of tolerant trees had been studied such as, production of fruits, seediness and taste of fruits. A positive correlation between CT values and production of mature fruits among the tolerant trees. Concerning to seediness of fruits, most of seedless trees have been infected by Clas, while seedy trees tend to produce more non-infected trees with HLB. Taste of fruits from non-infected trees was better than those from infected trees.

Conclusively, from these results, it could be concluded that, within individual species and among some citrus hybrid, number of progenies can be found that display substantial tolerance, and an ability to overcome and sometimes outgrow symptoms, this disease tolerance is not well correlated with estimated CLas populations. Future research utilizing these results for genomic selection in citrus populations will be performed.

Keywords: Huanglongbing; Citrus; Evaluation; Crosses; Tolerance.

\section{INTRODUCTION}

Huanglongbing (HLB) or citrus greening is considered one of the most dangerous and destructive diseases of citrus trees all over the world. This disease is caused by a phloem-limited bacterium called Candidatus librebacter which has not been cultured yet. Three major strains of this bacterium, Asiaticus, Africanus and Americanus have been differentiated on the basis of environmental conditions and insect vector (Coletta-Filho et al. 2004; Garnier et al. 2000). HLB is transmitted through different means; infected propagation sources, the parasitic plant dodder (Cuscuta sp.), and insect vectors in nature. Citrus psyllid have been identified as the most potent insect vector for the transmission of the disease. Two species, Diaphorina citri and Triozaerytreae, are known as vectors of specific strains such as Asiaticus, Americanus and Africanus of bacterial inoculum, respectively (do Carmo Teixeira et al. 2005; Halbert and Manjunath 2004). Transmission of the pathogen has been described and reviewed in detail by Manjunath et al. (2008). Pathogen populations inside 
the host tree induce the release of a specific volatile chemical, methyl salicylate, which attracts the vector population to feed on the infected tree and the pathogen is then ingested by the vector (Mann et al. 2012).

CLas' infection causes a weakness and death of infected trees, loss of fruit because of early abortion, also affects the fruit, and consequently, the juice. Symptomatic fruit are smaller, misshapen, and often contain aborted seeds compared to fruit from noninfected trees. Fruit from HLB infected tree tend to fall prematurely and those that remain on the tree fail to mature correctly and retain their green color, hence the name greening for this disease. Early studies on HLB symptomatic fruit in South Africa have reported that the juice was of poor quality and tasted bitter (McClean and Oberholzer 1965; McClean and Schwarz 1970). The fruits do not color properly, remaining green on the shaded side (hence the name "greening disease") (Bové 2006; Gottwald et al. 2007; Halbert and Manjunath 2004).

The symptoms on leaves diverge from full yellowing, asymmetric blotchy-mottling, or other chlorotic patterns which sometimes looks like mineral deficiency to intensive vein corking. Massive accumulation of starch and disruption of chloroplasts were found to be associated with vein phloem collapse in CLas -infected leaves and could account for the appearance of symptoms.

Nearly all cultivated and wild citrus species are likewise sensitive to HLB in varying degrees. However, within individual species and among some citrus hybrid families, number of accessions can be found that display substantial tolerance manifest as minimal symptom expression. Recently, some citrus cultivars released by the UF-CREC breeding program have exhibited tolerance to HLB, specifically 'LB8-9' (Sugar Belle) and '7-6-27' mandarin. To understand the mechanism of HLB tolerance, previous studies have either used sweet oranges or mandarins as susceptible types in comparisons with rough lemon (C. jambhiri) and HLB tolerant hybrids between Poncirus and Citrus (Albrecht and Bowman 2012). This approach complicates the understanding of plant-microbe interactions because the effect of candidate genes in tolerant trees may differ in the genetic backgrounds of susceptible trees due to epistasis.

Therefore, the objective of this study was to assess field tolerance to HLB among citrus breeding populations, which may lead to the development of efficient breeding methods utilizing HLB tolerant germplasm in a citrus cultivar improvement program. 


\section{MATERIALS AND METHODS}

\section{Field Assessments}

In the winter of 2015-2016, we examined HLB responses of 6609 trees from 1248 crosses made or mutations induced by the UF-CREC breeding program during years 1986-2008 (Table 1S). The parents used for these families included 89 different accessions of pomelo, mandarin, sweet orange, grapefruit, trifoliate orange, and other miscellaneous citrus species. Ploidy levels of the breeding populations included diploid, triploid and tetraploid. Eight field trials at the CREC, or in Haines City and Vero Beach, have been maintained using typical Florida citrus production practices.
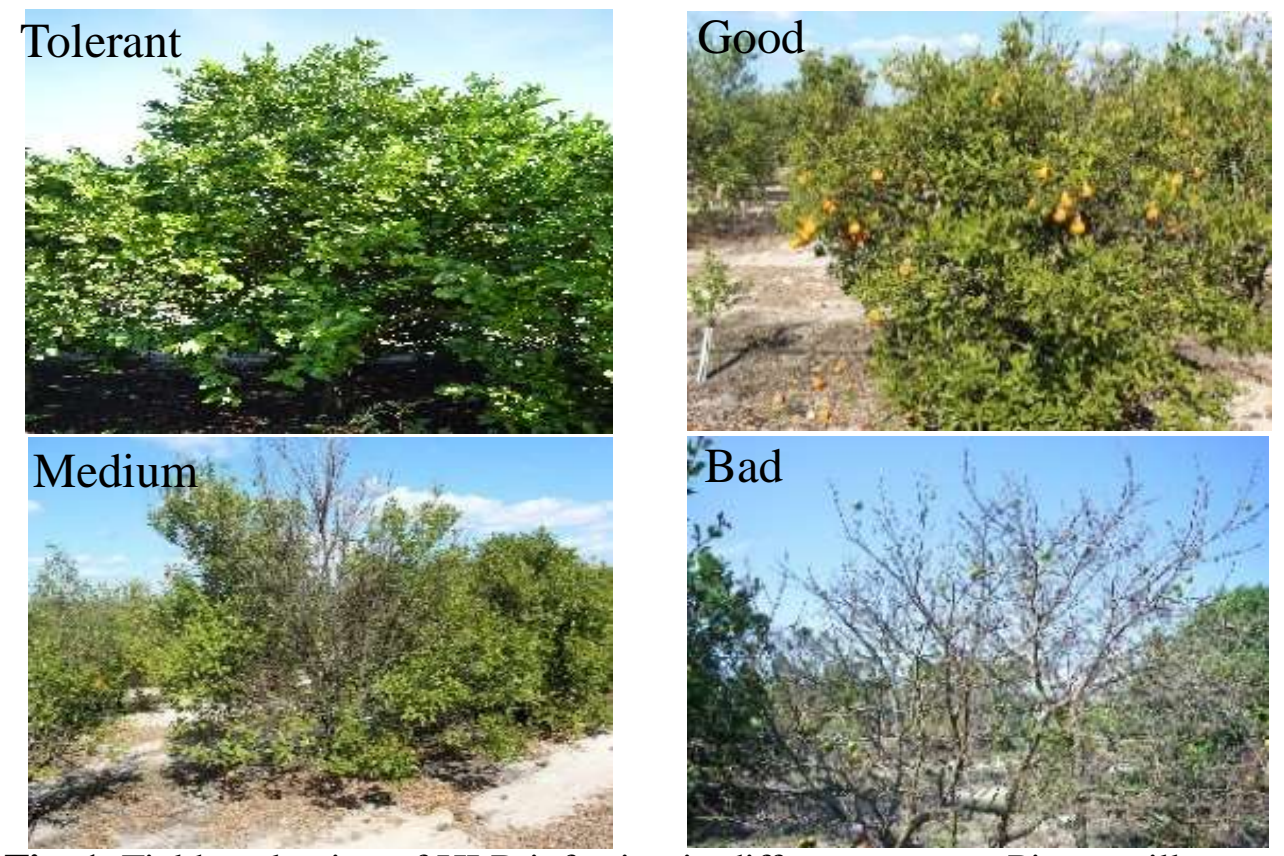

Fig. 1. Field evaluation of HLB infection in different crosses. Pictures illustrates the difference between tolerant ( $0 \%$ symptoms), good (0 to $25 \%$ symptoms), medium (26 to $50 \%$ symptoms), bad (51 to $99 \%$ symptoms), respectively in the field.

We observed very substantial differences in the speed which different individuals became affected by HLB, as well as in the severity of symptoms in the breeding populations. Examining of trees for disease symptoms was carried out using HLB field identification guides (Spann et al. 2010). Generally, the trees were divided into 5 grades according to the following ranking system (1=tolerant, 
$2=$ good looking, $3=$ =medium, 4=bad, 5=dead) trees (Fig. 1). These rankings were made based on the severity of the disease symptoms, tolerant trees ( $\% 0$ symptoms), good trees (less than \%25 symptoms), medium (\%25 to \%50 symptoms), bad trees (more than \%50 symptoms), dead trees were completely died (Albrecht and Bowman 2011), those symptoms like asymmetrical blotchy leaf mottle which was observed on most of the trees; bright yellow corky leaf veins, foliar yellowing and defoliation, leading to a thin canopy, twig and branch dieback and tree decline, which was substantial in large number of trees.

The fruit produced by infected trees is small, green, underdeveloped, and misshapen, with aborted seeds and bitter in taste. Fruits also have higher acid and lower sugar content. The fruits do not color properly, remaining green on the shaded side (hence the name "greening disease") (Bové 2006; Gottwald et al. 2007; Halbert and Manjunath 2004). These symptoms were substantially noted in the diseased trees, but they could also be observed in some healthy trees, as well.

After HLB visual evaluation for every tree in the field, we selected the tolerant trees according to our visual characterization, to assess the amount of production especially mature fruits by counting the number of fruits per tree and we gave this character four categories depending on number of fruits; $(0=$ no fruits, $1=$ few (less than 10 fruits per tree), 2= medium (between 10 to 20 fruits on the tree) and $3=$ high (more than 20 fruits per tree). Stover et al. (2016) all scion displayed increased cropping, greater than 20 fruit/tree.

Also, fruit taste had been assessed that is varied between $(0=\mathrm{bad}$, $1=$ medium and $2=$ good taste). Also, seediness was assessed by checking and counting the number of seeds in the fruits from each tree $(0=$ abortion seeds (brown and aborted seeds), 1=seedless (no seeds), 2=few seeds (less than 4 seeds) and $3=$ many seeds (more than 4 seeds)).

\section{Pathogen Detection with PCR Analysis}

Twelve fully expanded and old leaves were collected randomly from each tolerant tree with or without symptoms of HLB. The leaves were kept in plastic bags and refrigerated, then sent out to a commercial HLB diagnostic lab for DNA extraction and qPCR detection of Ct values. DNA was extracted from leaf midribs and petioles by using the plant DNeasy Mini Kit (Qiagen, Valencia, CA) according to manufacturer's instructions. Real- time PCR assays were performed according to Li et al. (2006) . Amplifications were performed using a real-time PCR system Agilent Mx3005P System (Agilent Technology) using a Brilliant III Ultra-Fast QPCR Master Mix (Agilent Technology). The industry standard for HLB diagnoses were applied; specifically, cycle threshold $(\mathrm{Ct})$ values $<32$ were 
considered CLas-positive. The statistical analysis of the results was done by using JMP software.

\section{RESULTS}

\section{Field Assessment}

Tolerant trees

The present results illustrate that the tolerant trees represent very low percentage $(5.3 \%)$ comparing to the other categories in the field evaluation for symptoms of HLB disease (Fig. 2). Based on the number of trees in every cross, we can notice that more than $30 \%$ of cross \{(Clementine $\mathrm{x}$ Temple) $\mathrm{x}$ C. ichangensis $\}$ were tolerant trees, followed by $\{($ Clementine $\mathrm{x}$ Temple $) \mathrm{x}$ Swingle $\}$ with ratio of $22.72 \%$ tolerant trees, (Fig.3A).

\section{Good trees}

From our studying we found $23.7 \%$ good trees between all evaluated trees. (Fig. 2). This cultivar (C528/Cleo) had $96.5 \%$ good trees between all its trees, followed by those crosses \{(Ellen x (page+Ortanique) $\mathrm{x}$ (Rhode Red+Dancy)), (Riley NR1 Pomelo 2 x McRed) and (Nules x (Hamlin+Dancy)) $\}$ with more than $70 \%$ good trees between all of them trees (Fig. 3B).

\section{Medium trees}

Medium trees with HLB symptoms between (25\%-50\%) represent the highest category in this study (32.8\%) between all the other categories (Fig.2). Cross (DPI 4-6 (red Java) x H.B.) has $70 \%$ from its trees that were medium trees, following by (H.B. x DPI 4-6 (Red Java)), (King Mandarin x Seedless Kishu). (Lee $\mathrm{x}$ Murcott) and finally (Clementine $\mathrm{x}$ Temple) $\mathrm{x}$ ortanique, with $(60.56 \%, 58.06 \%, 52.17 \%$ and 50\%), respectively (Fig. 3C).

\section{Bad trees}

The trees older than 7 years showed $15.4 \%$ bad trees between them (Fig. 2 ). Those trees were really infected, and the symptoms covered more than $50 \%$ from the tree branches. Fallglo x (Nova + Osceola) had most of bad trees while Citrus. ichangensis had the least percentage of bad trees between all its trees, (44\% and 32.3\%, respectively) (Fig. 3D). On the other hand, there were some crosses didn't have any bad trees for example \{(Nules x W.murcott), (Nules x 921), (Red Java x Page), (Lee x Murcott), (Nules x (Succari + Page)), (Shan Tian You) $\}$ as shown in Table 1. 
Table 1. The cultivars which have no bad trees.

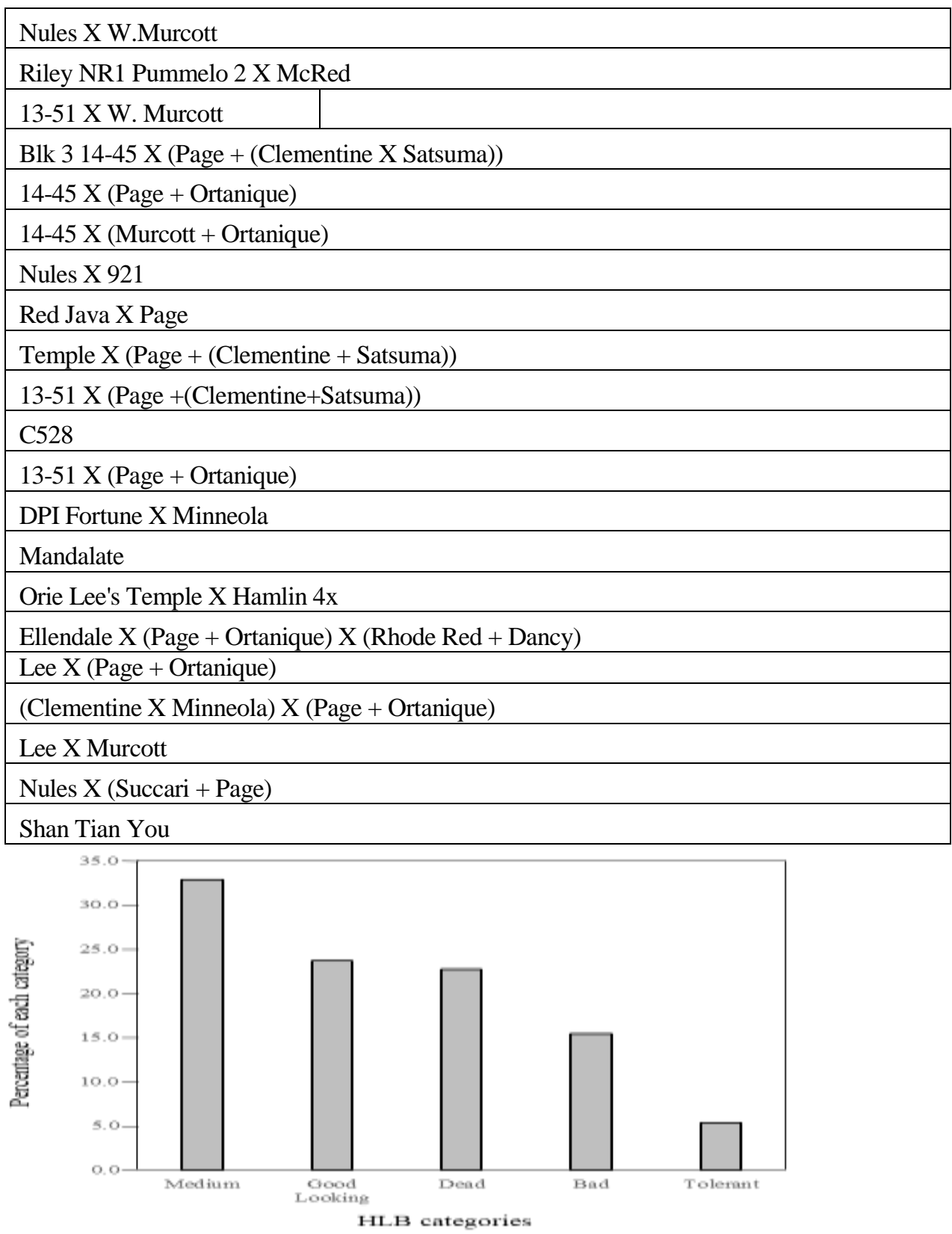

Fig. 2. Different categories of HLB in Field evaluation and percentage of each category. 

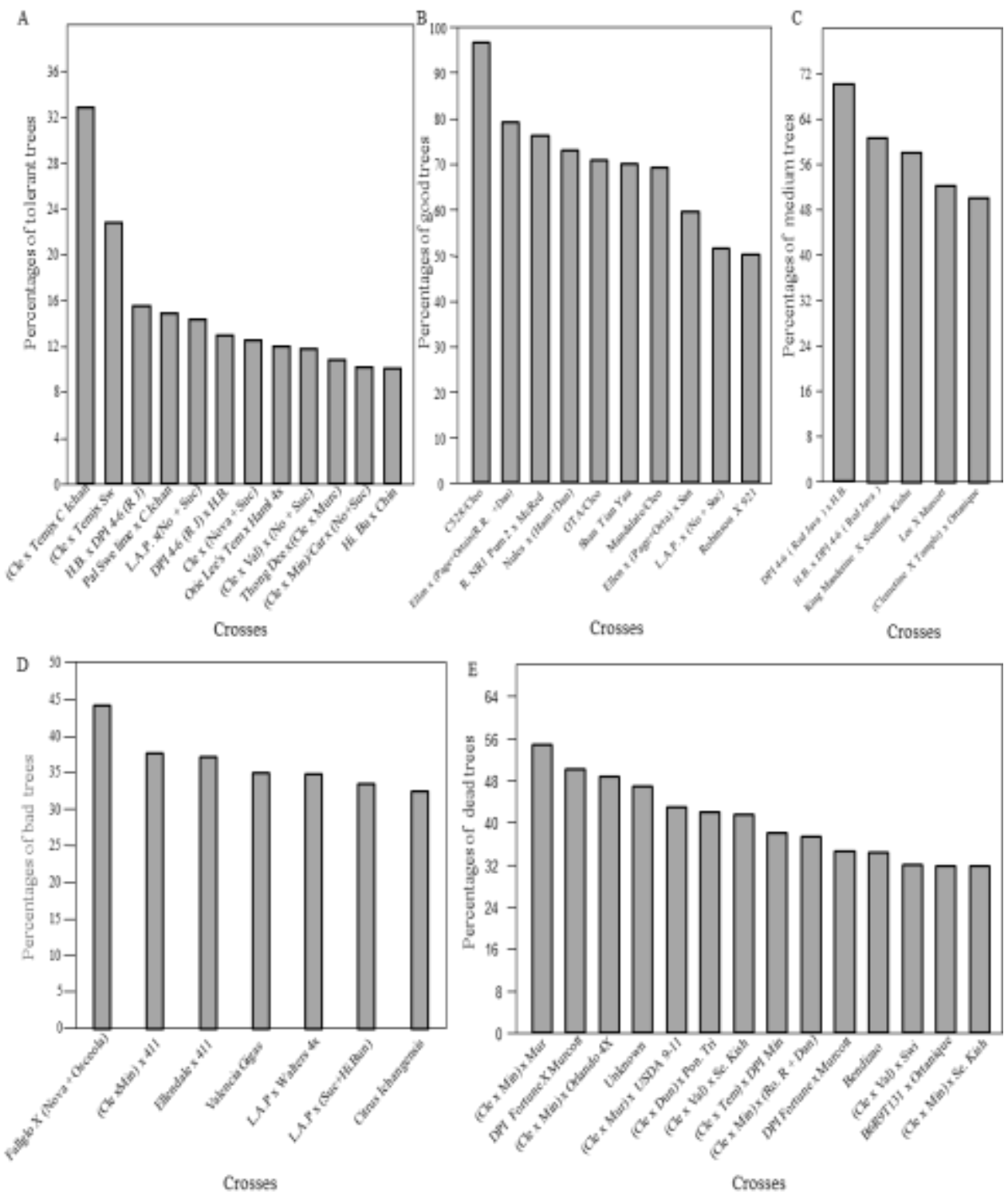

Fig. 3. Different categories of HLB visual evaluation in different crosses. And percentages of: A) Most tolerant crosses; B) Most good-looking crosses; C) Most medium crosses; D) Most of bad crosses and E) Most dead crosses. Crosses full names and abbreviations listed in (Table 2S). 


\section{Dead trees}

From our field surveying, we found $22.7 \%$ dead trees in different crosses and mutations (Fig.2). Most of those dead trees were in those two crosses

Clementine X Minneola) X Murcott) with $54.70 \%$ dead trees, followed by (DPI Fortune X Murcott) with 50\% dead trees, while both (Clementine $\mathrm{x}$ Minneola) x Seedless kishu and (Daisy Mandarin x Seedless Kishu) had the least percentage of dead trees with $31.60 \%$ and $30.80 \%$, respectively (Fig. 3E).

\section{Characterization of tolerant trees}

After visual characterization of all trees in all the blocks, the tolerant trees were selected for some studies such as checking CT value by qPCR analysis, cropping, taste of fruits and seediness. The correlation between CT value and cropping, seediness and taste of fruits had been assessed.

\section{PCR Analysis}

Among all visual tolerant trees $48.7 \%$ were $C$ Las-positive, which have CT value less than 32 , while $47.3 \%$ were CLas-negative with CT value equals or more than 32 (Fig. 4A). The best crosses for this study that have most tolerant trees with CT value =40, [ DPI 4-6 (Red Java ) x H.B, (Clementine X Minneola) X Chinotto, VB Temple X (Nova + Ortanique), VB Temple X (Nova + Succari), (Clementine X Temple) (Cleo) X c. ichangensis, Fallglo X (Nova + Osceola), H.B. x DPI 4-6 ( Red Java), Palestine Sweet Lime x C. ichangensis, (Clementine X Minneola) X (Nova + Succari) (Fig.4E).

\section{Number of fruits (cropping)}

Number of mature fruits for every tolerant tree had been determined. Most of trees didn't have a big number, the greatest hybrids in number of fruits [(Clementine X Temple) X Swingle, Clementine x (Nova+Succari) and Kansu sweet orange with $40 \%$ high production compared with the other categories of production in the same cross. The infected fruits had many symptoms such as misshapen, smaller and green at the stylar end of the fruit. Generally, we noticed a positive correlation between $\mathrm{CT}$ values and production of mature fruits among the tolerant trees, by increasing CT value, the number of fruits had been increased too. On the other hand, the production was really infected and low all over the field not just in infected trees but the tolerant trees too. (Fig.4B).

\section{Seeds}

The obtained data showed that $35.7 \%$ of tolerant trees had fruits with many seeds, on the other hand, 5.9\% from the tolerant trees have few seeds in 

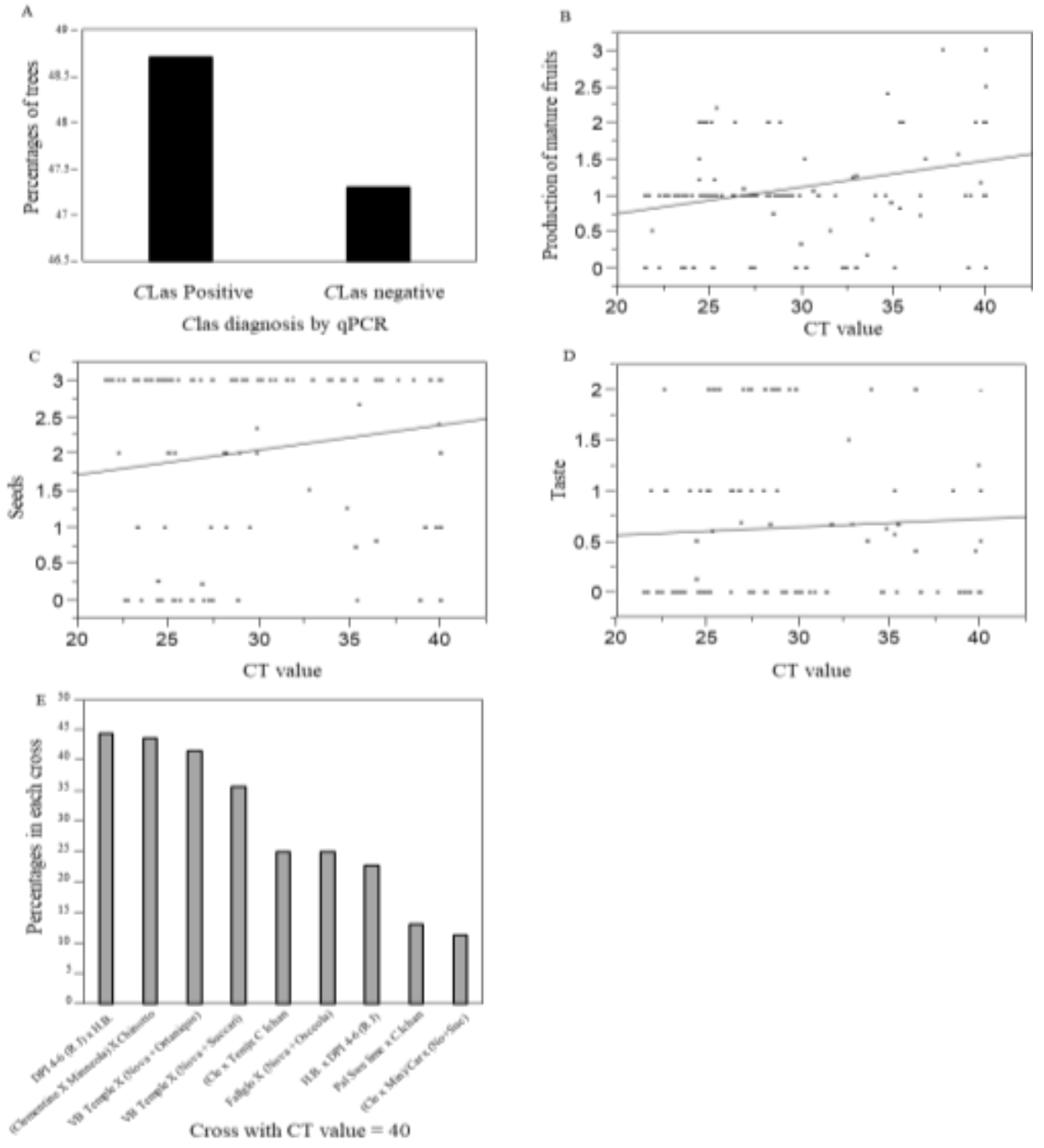

Fig. 4. Clas diagnosis for visual tolerant trees by $\mathrm{qPCR}$ and correlation between $\mathrm{CT}$ value and some studied characters. A) The ratio between CLas positive and CLas negative between all visual tolerant trees; Correlation between $\mathrm{CT}$ value and $\mathrm{B}$ ) Production of mature fruits; C) Seediness; and D) Taste of fruits and E) Tolerant crosses with $\mathrm{CT}$ value $=40$ and percentage of those tolerant in each cross. 
the fruits, while $18.7 \%$ from those trees had seedless fruits, most of them in this triploid hybrid ((Clementine X Minneola) X (Nova + Succari)), and $4.8 \%$ had abortion seeds, this kind of seeds is considered one of HLB symptoms, that's why we noticed that the cross with biggest number of abortion seeds was [Fallglo $\mathrm{x}$ (Nova + Osceola)] and it is the same cross with the biggest number of bad trees, this result can reflect the effect of HLB disease on citrus seeds quality. From the relationship between seediness and CT value we found that most of seedless trees have been infected by Clas, while seedy trees tend to produce more non-infected trees with HLB (Fig. 4C). This result can lead to good way for fighting this serious disease by breeding program, maybe there is an effect for presence of seeds in fruits and tolerance to HLB.

\section{Taste of fruits}

The fruits of all tolerant trees were tasted, $18.4 \%$ of them had good taste, most of them in this cross ((Clementine X Minneola) X (Nova + Succari)), 7.4\% trees had medium taste (not good or not bad), while most of the visual tolerant trees had fruits with bad taste (40.2\%). (Fig. 4D) illustrates that the taste of fruits from non-infected trees was better than those from infected trees.

\section{DISCUSSION}

Huanglongbing (HLB) has become a global problem that fights the production of citrus. The disease is widely spread in Asia, Africa and not long ago in America (Jagoueix et al. 1994; do Carmo Teixeira et al. 2005)Unfortunately, most of cultivated and wild citrus species are likewise sensitive to HLB in varying degrees. Although, some citrus species and relatives were considered tolerant to this disease (McClean and Schwarz 1970; Miyakawa 1980). This disease is really hard to be assessed in the field because the symptoms resemble other disease (such as stubborn disease) and nutritional deficiencies (such as zinc), those results illustrated by(Grafton-Cardwell et al. 2006).

One of the major difficulties for detection of HLB disease is that, symptoms are unevenly distributed within infected trees (Folimonova et al. 2009). That's why we didn't depend on just visual evaluation for characterization the trees, but more studies had been conducted for the tolerant trees. 
This study illustrated that very little percent from all the studied trees were tolerant compared with the other categories. That means very big loss happened as an effect to HLB disease. HLB has become the most destructive citrus disease all over the world, where it generates substantial economic losses (Bové 2006). The cross \{(Clementine x Temple) x C. ichangensis $\}$ includes most of HLB tolerant trees in visual evaluation. These results mean that this cross considered the best cross in this study. May be this related to Temple parent, (Stover et al. 2015) assessed HLB in diverse cultivars in commercial groves with high HLB incidence and conducted that 'Temple' had the least symptoms for HLB comparing to 'Murcott' had the most symptoms.

Concerning to tolerant trees, just $8.8 \%$ from all tolerant trees had big production, these results refer to very big loss in the production of trees and this had been conducted before by Bové (2006). The fruits in most of trees had many symptoms such as misshapen, smaller and green at the stylar end of the fruit, those results had been conducted before by GraftonCardwell et al. (2006). PCR results for visual tolerant illustrated that almost 1:1 ratio, CLas-positive to CLas-negative. Data illustrated that, $80 \%$ from those $C$ Las-negative have $C T$ value $=40$. The cross (Clementine $\mathrm{X}$ Temple) X C. ichangensis has most of those tolerant trees with CT value $=40$. (Stover et al. 2015) resulted that 'Temple' showed the lowest (Las) titer comparing to 'Murcott' had the highest titers. Taste of fruits differed between all tolerant trees, $18.4 \%$ of them had good taste, most of them been included in this somatic hybrid ((Clementine X Minneola) X (Nova + Succari)), that was one of the best tolerant progenies in this study, also had most trees of seedless fruits.

In recent years, HLB has caused substantial economic losses to the citrus industry by shortening the tree life and reducing productivity with poor quality colorless fruit left on the trees (Bové 2006). The greatest hybrids in number of fruits [(Clementine X Temple) X Swingle], this can be related to Temple that showed significantly greater cropping than 'Hamlin' (Stover et al. 2016).

A significant correlation had been noticed between CT values and the taste of fruits. Most of bad taste fruits were included in infected trees. The infected fruits were bitter and sour. And this had been summarized before by Grafton-Cardwell et al. (2006), HLB infected fruits are small, 
green, under developed, misshapen and bitter in taste. Thus, fruit cannot even be marketed as juice.

Most of abortion seeds were included in the infected trees with CT value less than 32 and reduced in non-infected trees with CT value more than 32, those results agree with (Capoor et al. 1974) and (McClean and Schwarz 1970). They noticed that seed abortion is common symptom for HLB infected fruits despite the absence of apparent disease symptoms on fruit and leaves.et al

From our study, we illustrated that most of seedless trees have been infected by Clas, while seedy trees tend to produce more non-infected trees, but these results don't agree with (Albrecht and Bowman 2011), Fruit average seed did not differ significantly $(\mathrm{P}>0.05)$ between symptomatic and symptomless trees.

In summary, HLB tolerance is complex quantitative trait, and controlled by many genes. To provide HLB tolerant cultivars as well as good flavor, genomic assisted breeding could increase the efficiency and precision of citrus improvement.

\section{CONCLUSION}

Use of resistant or tolerant citrus plants could be the most economically way of managing HLB disease. The objective of this study was to look at the impacts of genetically modified individuals of citrus on HLB disease. The cross (Clementine x Temple) x C. ichangensis, was the best cross in the field evaluation, showed less severe symptoms than all the other trees. Also, it has most of tolerant trees with $\mathrm{CT}$ value $=40$. The severity of HLB disease is often measured by visual assessment. Visual assessment is rapid and useful when hundreds of trees should be evaluated. Although, it is not enough for evaluation.

As expected, some differences were observed in the performance of the HLB infected trees on the genetically diverse individuals included in the study. However, it should be noted that the study was done over a short period of time (less than a year). Longer studies and other additional field trials along with greenhouse studies will be done to validate any conclusions. 
Table IS. All cultivars in this study.

\begin{tabular}{|c|c|c|c|}
\hline The tresses & $\begin{array}{l}\text { Number } \\
\text { of tres }\end{array}$ & The erosses & $\begin{array}{l}\text { Number } \\
\text { of trees }\end{array}$ \\
\hline (Clementine X Mimnsob) X (Nona + Sescrin) & 243 & Shadetis: & 33 \\
\hline (Clementine X Mirnsolji X Seedless Kishu & 212 & White Xandarin (Ponkan) & 33 \\
\hline Unknown & 177 & (Clementine X Duncan) X Sedless Kishe & 32 \\
\hline Daisy Mandarin X Seedless Kistre & 172 & IClememine X Mimneola) X Wahters $4 \mathrm{~s}$ & 32 \\
\hline (Clementine X Mimneab) X Orlando $4 \mathrm{x}$ & 168 & iClememine X Templet X Hertin + Dansy 4u & 32 \\
\hline VB Temple X (Nova + Otanequel & 163 & (Clementine X Teuple) X Othague & 32 \\
\hline Nules X (Hamlin + Daacy) & 159 & Orie Lee's Temole X Valencia ts & 32 \\
\hline (Clementine X Mimnab) X Chisesto & 136 & Cious ictungensis & 31 \\
\hline Clementric X (Clementine X Miresola) & 130 & Kine Manderin X Scodless Kustur & 31 \\
\hline 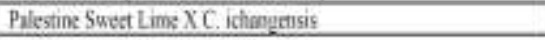 & 128 & 13-51 XiPaye + Clementine X Secsumai & 30 \\
\hline Fallylo Xi(Nora + Osceola) & 125 & (Clementine X Ninneolk) X Ruby & 29 \\
\hline B6R9T131 X Oranizųue & 123 & 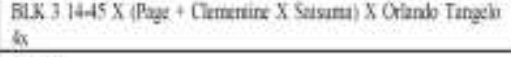 & 29 \\
\hline VB TempleX (Nova + Succari) & 103 & $\mathrm{C52 \sqrt {2 }}$ & 29 \\
\hline Low Akid Pummeto X Walters $4 \mathrm{x}$ & 98 & Ellendale X4II & 27 \\
\hline 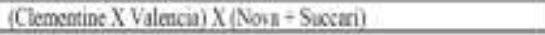 & 94 & LBER5T36 $X$ Imperial $4 x$ & 27 \\
\hline Nules X W. Mlumsont & 90 & 3 13-5! X (Page + Otaniqge) & 26 \\
\hline (Clememint X Mimneab) X (Nova + Suctari) & 89 & DPI Fentive X Mursou & 26 \\
\hline 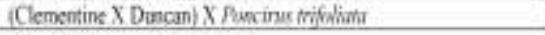 & 88 & DPI Fortine X Mimnoola & 26 \\
\hline Riley NRI Pummelo X McRed & BS & Mandalane & 26 \\
\hline Low Acid Pummelo X (Seckan + Findo Bunan) & 87 & Fhing Drapgen 2 & 23 \\
\hline Marised X AII & 50. & Orie Le's'semple X Hamlin $4 x$ & 25 \\
\hline (Clementine X Mimnoba) X 9.11 USDA & 78 & IClementine X ValencialX X Switgile & 24 \\
\hline Robinson X/Nora + Succam & 73 & Ellendale X (Pagz-Otaniquei X (Rhode Rod +Dzucy) & 24 \\
\hline (Clementine X Temple) X DF Mimeda & 71 & Lee X X (Page + Oranizue $)$ & 24 \\
\hline Fötune X (Nowa + Seccari) & $\pi$ & OTA & 24 \\
\hline H.B XDP $4-6$ (Red Java) & 71 & IClementine X Mimnoolai X Page + Ontatique) & 23 \\
\hline DPI+ 6 ; Rod /ma X X HB & 70 & Lee X Mursolt & 23 \\
\hline Low Acid Pummelo X (Nova + Succan) & 70 & Ndes X (Suckai + Page] & 23 \\
\hline Low Acid Pummelo X Yalencia dx & 70 & Valenciu Giass & 23 \\
\hline 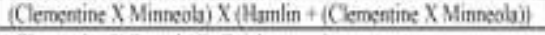 & $\theta$ & (Clementine X Minneola) (BS7R1453, 34) XV Vermilian & 22 \\
\hline (Clementins X Templa) XC. klungensis & 67 & [Clementine X Teruplei X Swingle & 22 \\
\hline (Clementine X Dentan) X Duecan & 65 & [Clementine X Murcouti) X USDA9-1] & 21 \\
\hline (Clementine X Mimneob) X Hamint $4 \mathrm{x}$ & 65 & Hindo Burtan XChincto & 20 \\
\hline (Clementine X Minneala) X Mercuitt & 64 & 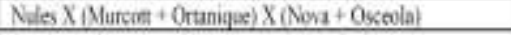 & 20 \\
\hline Clementine XOrtanda $4 x$ & 61 & Sin Tinn You & 20 \\
\hline (Clementine X Minnsola) X (Rohde Red + Dixcy) & 99 & [Clementine $X$ Valenciz) X Walkers $4 \mathrm{x}$ & 19 \\
\hline 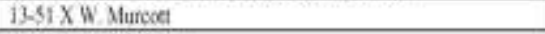 & 39 & Fremort & 19 \\
\hline Der Falloglo X S wingle & 59 & 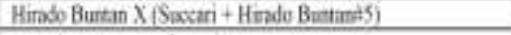 & 19 \\
\hline (Clementine X Minnsobi) X Foctune & 57 & Temple X (Nosa + Ostoda) & 19 \\
\hline (Clementine X Minneab) X Carrizs & 56 & Thong Dee X Mintecia Tanele & 19 \\
\hline (Clementine X Minneob) X Orlando Tangeto & 55 & (Clementinine X Duscan) X Pajerind is & 18 \\
\hline Def Fortunit X Muruoge & 55 & (Clementine X N(mineola) X Biy Tangeb b & 18 \\
\hline (Clementint X Valencia) X Scodless Kishe & 53 & 13-51 X(Muroon + (Clementine X Minoodla) & 18 \\
\hline $14-45 \times$ (Page + Clementine X Satsuma) & 53 & Moornal X Orlendo $4 x$ & 18 \\
\hline Let X Seedless Kishu & 52 & Sout Oratege X Ridge Pireapple & 18 \\
\hline B6R9T133 X Hemlinis & 51 & (Clementine X Minnoola) X Piserrind $4 \mathrm{x}$ & 17 \\
\hline $14-45 \times$ (Page + Ortanique) & 51 & Hrado Buntan X Hudsos & 17 \\
\hline Fortune $X$ Valescin $4 \mathrm{x}$ & 19 & Hadson $4 \mathrm{~N}$ & 17 \\
\hline (Clementine X Mimneab) X 4II & 48 & Lee X Fainchild & 17 \\
\hline (Clementine $X$ Valencia) $X$ Surugle & 47 & 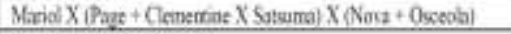 & 17 \\
\hline Elendale X (Pzge +Ortamique) X Sangainefli & 47 & Templa X Soodless Kiches & 17 \\
\hline Nakon X (Clamentine X Mirmeola) & 47 & [Clamentine X Minneda) X Murcest X (Valencia + Puse] & 16 \\
\hline 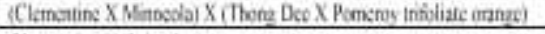 & 46 & B 6 R9Ti32X Ruby ax & 16 \\
\hline Clementine X Orlando $4 \mathrm{x}$ & 42 & Clenertine sedfings & 16 \\
\hline $14-45 \times$ (Mutcost + Ortanicue) & 41 & Ellendale seedlings & 16 \\
\hline Clementine X (Nova + Succaí) & +1) & Nakoe X Minneoli Tangalo & 16 \\
\hline Nule X921 & 40 & Slirnni & 16 \\
\hline Red lon X Pass & $\$ 0$ & (Clementine X Nimnecha) X [S I19 & 15 \\
\hline (Clementine X Mimneob) X Orlando & 38 & B6R9T131 X Dancy $4 \times$ & 15 \\
\hline Temple X (Page + Cloweetine X Sorsunia) & 37 & Ellendale X Orlando $4 \mathrm{x}$ & 15 \\
\hline Thens: Dee X (Clementing X Marcoti) & 37 & Hirads Burcan X Hadses & 15 \\
\hline Rotanson X921 & 36 & Nakon XPage & 15 \\
\hline Bendinos & 35 & Souther Faimis citrnges & 15 \\
\hline (Clementine X Minneob) X Orbanlo Tragelo X Valenciz $4 \mathrm{x}$ & 34 & (Clamentine X Hembin X Xwangle & 14 \\
\hline
\end{tabular}




\begin{tabular}{|c|c|c|c|}
\hline (Clemetitine X Minneola) X Valencia & 14 & CimersunasCamixo & 9 \\
\hline (Clementine X Minmeola) X Valencia $4 x$ & 14 & 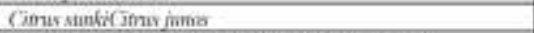 & 9 \\
\hline (Clementine X Minneola) Cernoo & 14 & Fiwicke orangeorange $X$ Asquesine FFoms sandi & 9 \\
\hline 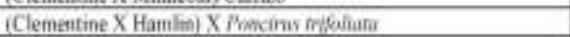 & 14 & 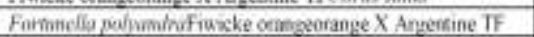 & 9 \\
\hline Liang Ping Yau & 14 & Hirado Buntan X Chinostof cossuaulla polymáni & 9 \\
\hline Rice Manderin & 14 & I.B4-19 X Suing keflirado Buntan X Chinotto & 9 \\
\hline Robriegon X Fairchild & 14 & Rolvingren X Puperrind 4X4xL.B4-19 X Saingle & 9 \\
\hline Robieson X US 119 & 14 & SF-12-2,31Robirison X Paperrind 4x & 9 \\
\hline VB Clamentine ds X 411 & 14 & Tehiti arange $X$ Argentime TFSF-12-2-33 & 9 \\
\hline (Clementine X Minneolai) X V Valencia + Page) & 13 & (Clementind X Minnecla) Tahiti onatge X Avgentine TF & 9 \\
\hline 104US 897 & 13 & $\begin{array}{l}\text { (Clementine X Tample) X (Vakenciat Robinson X. Temple) } \\
\text { (Clementine X Minneola) }\end{array}$ & 8 \\
\hline Clamentine X (Pmk Marsh + Murcoti) & 13 & $\begin{array}{l}\text { (Clementine X Valescia) X Orfando Tangela } 4 \times \text { (Clementine } \\
X \text { Temple) X Valenciat Robinocn X Temple) }\end{array}$ & 8 \\
\hline Khangensis: & 13 & $\begin{array}{l}\text { (Clementme X Tenipie) X (K+V) (Clementibe X Valenta) X } \\
\text { Orlando Tangelo 4x }\end{array}$ & 8 \\
\hline Marisol X Succari 4x & 13 & Cas Ju [Clementine $\mathrm{X}$ Temple $\mathrm{X}(\mathrm{K}+\mathrm{V})$ & 8 \\
\hline Palestine Sweet Lime X Gou Tou & 13 & DFI King Ha X MarahCas Ju & 8 \\
\hline Pimpled Manderiit & 13 & Fallobo X MutscuDPI King H4 X Marsh. & 8 \\
\hline 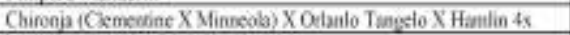 & 12 & Golden PeaF allglo X Marcoit & 8 \\
\hline Domimicas Wild Gape fnin Chironia & 12 & Mercer PaseGolden Pea & 8 \\
\hline Fallido X Fair chiid Dominicin Wild Grapefnuit & 12 & Robienscen X RubyMercer Pare & 8 \\
\hline M132Fallyglo X Fairchild & 12 & SR3R(101-MR2CZORobingon X Ruby & 8 \\
\hline Sue Lindz Temple X (Nova + Sxcari) MI32 & 12 & S. VmcecKR.3RU01-MB2 CZO & 8 \\
\hline 3931 Soe Linda Tengle X (Nova + Succan) & 12 & (Clementine X Mimneolai) X 80-95t. Vincent & 8 \\
\hline LB 4-8 X Ortanique 3931 & ॥ & $\begin{array}{l}\text { (Clementine X Valentia) X Secoly Marsh (Clamentine X } \\
\text { Minneala) X so-9 }\end{array}$ & 7 \\
\hline Lisbon X Chinnttol. B 4-8. XOntanigat & II & $\begin{array}{l}\text { (Clementine } \mathrm{X} \text { Valencia) (B7R LAT36) X Vermiluan Hong } \\
\text { (Clementine X Valescia) X Seedly Markh. }\end{array}$ & 7 \\
\hline NB-7.34JISS997Lisbon XChinotso & II & $\begin{array}{l}\text { Clementine X (Succari + Dascy) (Clementine X Valencia) } \\
\text { (B7R14T36) X Vermilian Hogr }\end{array}$ & 7 \\
\hline Nules X W MurcotiNB-7.34US897 & II & 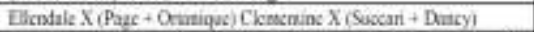 & 7 \\
\hline $\begin{array}{l}\text { (Clementine X Mumenla) X (Page + Clementine X Satsuma) } \\
\text { Nules X W Murcou }\end{array}$ & 11 & $\begin{array}{l}\text { Fawocke Orange } X \text { Flying Dragnn If Ellendale } X \\
\text { (PhestOrasigge) }\end{array}$ & $\tau$ \\
\hline $\begin{array}{l}\text { (Clementine X Minntola) X Ortanigue (Clementise X Afimteola) } \\
\text { X(Pye + Clamentine X Satsuma) }\end{array}$ & 10 & Hong Nin Mon Fiuscke Orange X Flying Dragos TE & 7 \\
\hline $\begin{array}{l}\text { (Clementine X Murcott) X Paperind Ax (Clementine X Mimneola) } \\
\text { X Ontanique }\end{array}$ & 10 & Lee X (Murcoet + iClementine X Minneola) Hong Nin Men & 7 \\
\hline $\begin{array}{l}\text { (Clementine X Valencia) (BFR/4T35, 36) X Bendizao } \\
\text { (Clementine X Murcott) X Papernind } 4 x\end{array}$ & 10 & R3NA02-RALee X(Blurcoet + (Clementine X Minneola) & $?$ \\
\hline $\begin{array}{l}\text { (Clementine X Tenple) X Sunburst (Clementine X Valencsa) ( } \\
\text { BJRI4T35, 36) X Bendias }\end{array}$ & 10 & Ruby X Fying Dragan TFR3NA0a-RA & 7 \\
\hline $\begin{array}{l}\text { Clamentime X (Hamlin X (Clementine X Minnecla)) iClementive } \\
\text { X Temple) X Sunburst }\end{array}$ & 10 & Sackl CTCCRuby X Fying Dragan TF & 7 \\
\hline $\begin{array}{l}\text { Fiwikke crangecorange X CarmzoClementine X (Hamlin X } \\
\text { (Clementine X Minneola) }\end{array}$ & 10 & Vasgasay Lewod X (D) 6- 13) X 1575-21Snad CXCC & 7 \\
\hline Oris Lee's Temple X Orlando 4x Fiwicke Orange X Camizo & to & $\begin{array}{l}\text { (Clementine X Valencia) X HamlinVangasy Lemon X (Dyoi } \\
6-13 ; X 1575-21\end{array}$ & 7 \\
\hline 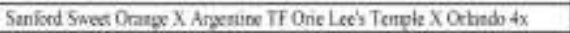 & 10 & IClementine X Valeacia) X Ruby (Clemenume X Valarese) X Hamin & 6 \\
\hline $\begin{array}{l}\text { Sanford Saeet Orange X Flying Dragoo TF Sanfond Sweet Ornage } \\
\text { X Arugusine TF }\end{array}$ & 10 & $\begin{array}{l}\text { (Clemetine X Temple) (Cleo) X Swingle (Clemestine X } \\
\text { Yalencia) X Ruby }\end{array}$ & 6 \\
\hline $\begin{array}{l}\text { Tahiti ocange X Flying Dragon If Sanford Sweet Orange X } \\
\text { Flying Dragee TF }\end{array}$ & to & 2014 (Clemetine X Templer (Cleo) X Swingle & 6 \\
\hline Wilking seedliegs Tahiti erange X Flyine Dragen If & 10 & 22242014 & 6 \\
\hline $\begin{array}{l}\text { (Clemsutine X Duncan) (BTR14T23,24,25) X Valescin } 4 \mathrm{x} \\
\text { Wilking seedlings }\end{array}$ & 10 & Eureka X Chisono2224 & 6 \\
\hline $\begin{array}{l}\text { (Clemantine X Duncan) X (Nona + Soceari) (Clementine X } \\
\text { Duncan)(B7R14723,24,25) X Valencia } 4 x\end{array}$ & 9 & Fortune $X$ ValencizEureka $X$ Clinono & 6 \\
\hline $\begin{array}{l}\text { (Clementine X Minneola) X Murcolt X Seedless Kiahu } \\
\text { (Clementine X Durcan) X (Nova + Succart) }\end{array}$ & 9 & Gft. Chimen 3Fortune X Valescia & 6 \\
\hline $\begin{array}{l}\text { (Clementine X Mimneofa) X Valescia is (Clementine X } \\
\text { Minneala) X Murcott X Seedless Kashu }\end{array}$ & 9 & LB 4.3 X Chinsttotift Chimen 3 & 6 \\
\hline 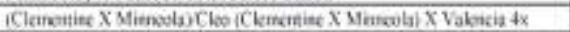 & 9 & Murceet 4NCleol B 4-3 X Chinotte & 6 \\
\hline (Clementine X Muncoet) X Valenesa (Clemernise X Minneob) Coo & 9 & 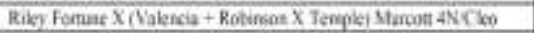 & 6 \\
\hline $\begin{array}{l}\text { (Clementine X Vakencia) X (Naboo X Flying Dragen IF) } \\
\text { (Clementine X Mureutt) X Valencis. }\end{array}$ & 9 & Rootsprout Riley Foctune X (Valencu + Robcrown X Teusple) & 6 \\
\hline $\begin{array}{l}\text { B23ERST36 (Low Acid Pummelo) X Wakers Clementine X } \\
\text { Vakencia) X (Nakion X Flymg Dragnn TF) }\end{array}$ & 9 & Reby X Arpentine TFRootsprout & 6 \\
\hline CarreaB23ER5T36 (Low Acid Punmelo) X Walters ts & 9 & Satsuma X Suntourskekby X Argentine it & 6 \\
\hline
\end{tabular}




\begin{tabular}{|c|c|c|c|}
\hline Xe SemSisuma X Seabirst & 6 & BORTTI3I X Hamlin $4 \times 3875$ & 5 \\
\hline 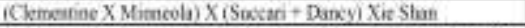 & 6 & BGBRT1131 X Valmica $4 \times B 687 T 131 \times$ Hemlin $4 x$ & 3 \\
\hline 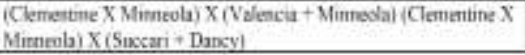 & 5 & Kana (SRA,O6R7) I I s Valetcia 4X & 5 \\
\hline 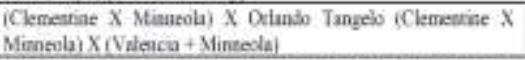 & 3 & 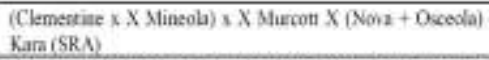 & 5 \\
\hline 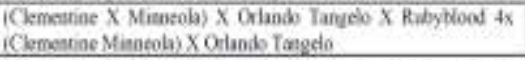 & 5 & 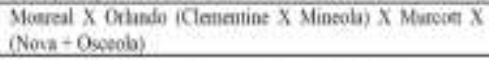 & 5 \\
\hline 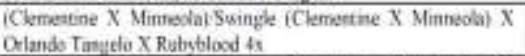 & 5 & Palestitne Sweet Lime X SwasteMcareal X Onintdo & 5 \\
\hline $\begin{array}{l}\text { IClementine X Murroit) X Papernind (Clenentine X X } \\
\text { Mimenluiswinde }\end{array}$ & 5 & S4HADI-3LE? Palestine Swoet Lime X Suingle & 5 \\
\hline $\begin{array}{l}\text { IClemeatiae X Valescia)Clos (Clementiee X Starcom) X } \\
\text { Pasernind }\end{array}$ & 3 & 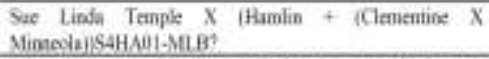 & 3 \\
\hline 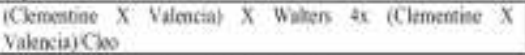 & 5 & 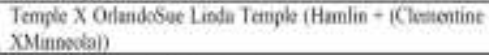 & 5 \\
\hline 3637 (Chenentine XValencia) X Walters $4 x$ & 5 & Tu Nis ManTempk X Orhando & 5 \\
\hline 38753695 & 3 & Ta Nie Mon & 5 \\
\hline
\end{tabular}

Table 2S. The full names and the abbreviations for some crosses

\begin{tabular}{|c|c|}
\hline Foll mame & Ablreviatians \\
\hline (Clemertiae $x$ Tenpla) iCleoix C Ichunyessus. & (Clex Tem x C khan \\
\hline (Clamartine x Temple) iCleoi $\times$ Sumgh & Clex Temb Su \\
\hline H. $\times$. DP 4.6 (Red Jara) & H.B. $\times$ DP $[4.6(R)]$ \\
\hline 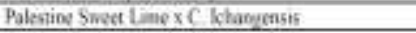 & Pal Swe lime oc khas \\
\hline Low Acid Pammeló x (Nora + Saccan) & 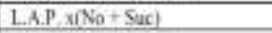 \\
\hline $\mathrm{DPf}+6$ ( Red Ima $) \times \mathrm{HB}$ & DP $\{4-6\{R]\} \times B B$ \\
\hline Clementine $x$ (Nover-Sacean) & Cles (Nona+Suk) \\
\hline Orie Lets Ternple $\mathrm{x}$ lismlia $4 \mathrm{X}$ & One l.se's Tem $\mathrm{x}$ Haml $4 \mathrm{x}$ \\
\hline (Clementite $x$ Valimaial a (Nonat-Suceari) & $(C l e x$ Val $) \times\left(\mathrm{No}_{0}+\mathrm{S}_{\mathrm{ax}}\right)$ \\
\hline Thong Des a (Clemeatine $x$ N/urtott) & 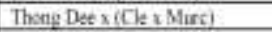 \\
\hline 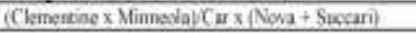 & (Clex Min) Car $\times(\mathrm{Ne}+\mathrm{Suc})$ \\
\hline Ifindo Buman s Chanotio & Hi. Bra $\times$ Chin \\
\hline C525Clen & C52RCLeo \\
\hline Ellendale $x$ (Pagetorainaque $\times$ (Rhode Red +Dancys & Ellen x (Pagetoraxik R +Dam) \\
\hline Ruley NRI Pusumelo 2 a McRled & R NRI Pum 2 2 McRed \\
\hline 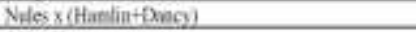 & Nules s:(tiam+Dan) \\
\hline OTACleo & OTACXN \\
\hline Shan Tim Yas & Shan Tan Ym \\
\hline Mandabiecleo & Mandahote Cles \\
\hline 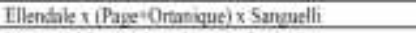 & Ellen $\times\left(P_{2 a g}+\right.$ Ora $) \times S a n$ \\
\hline Low Acid Prammelox (Nowa + Saxcan) & L.A.P $\times\left(\mathrm{N}_{0}+\mathrm{Suc}_{\mathrm{C}}\right.$ \\
\hline Robusean $\times 521$ & Robimion $\times 921$ \\
\hline Fhiag Dryon 2 & Flsing Dragas 2 \\
\hline Fallylos (Nora + Oscroha) & Fallghex (Noเa + Osceola $)$ \\
\hline (Clemerrise $x$ Mmimodialx 411 & $(\mathrm{Cle} \times \mathrm{Min}) \times 41]$ \\
\hline Ellendik r 4II & Ellandale $\times 411$ \\
\hline Valencia Geass & Vylenca Gian \\
\hline Low Acid Pammelox Wahers $4 \mathrm{X}$ & 1. A.P I Walten 4x \\
\hline 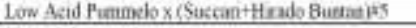 & L.A.PSISActHi.Ban \\
\hline Citris lchangensis & Crans khangensis \\
\hline (Clementise x Mirmodia) x Marcont & (Clex Min) x Mfor \\
\hline DPI Fortine $\mathrm{x}$ Murcoll & DPI Forture X Xlurcoll \\
\hline (Clemertine $x$ Minnodla) $x$ Otands AX & (Cles Stin) $\times$ Orlando $4 \mathrm{X}$ \\
\hline Ithknown & Unknowet \\
\hline (Clemerriale $x$ Murootri) $x$ USDA 9.11 & (Clex Mur) x DSDA 9.11 \\
\hline Clemettine X Drecmi s Poecins Trisklias & (Cle x Daij) Paet Tri \\
\hline 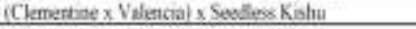 & $($ Clex Val) $\times$ Se Kist \\
\hline 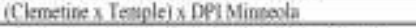 & $(C l e x \operatorname{Tem}) \times$ DPI Mfa \\
\hline 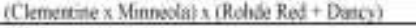 & (Cles Mliniso(Ha $\mathrm{R}+\mathrm{Dani}$ \\
\hline DPIFantune $x$ Murcat & DPI Fortune $\mathbf{x}$ Morant \\
\hline Bendire & Bendiras \\
\hline (Clameutane x Yalencia) $x$ Swagle & $(C \mathrm{C} \times \mathrm{Val}) \times \mathrm{Spoi}$ \\
\hline B6R9TI31 x Ortanizut & BCR9T131 s Ontanique \\
\hline (Ckmentale x Minnodai x Seedless Kustiu & (Clex Min) x Se Ksoli \\
\hline
\end{tabular}




\section{REFERENCES}

Albrecht, U., and K. D. Bowman (2011). Tolerance of the trifoliate citrus hybrid US-897 (Citrus reticulate Blanco $\times$ poncirus trifoliata L. Raf.) to huanglongbing. HortScience. 46:16-22.

Albrecht, U., and K. D. Bowman (2012). Transcriptional response of susceptible and tolerant citrus to infection with Candidatus Liberibacter asiaticus. Plant Sci. 185-186:118-130.

Bové, J. M. (2006). Huanglongbing: A destructive, newly-emerging, centuryold disease of citrus. J. Plant Pathol. 88:7-37.

Capoor, S. P., D. G. Rao, and S. M. Viswanath (1974). Greening disease of citrus in the deccan trap country and its relationship with the vector, Diaphorina citri kuwayama. Proc. 6th Int. Organ. Citrus Virol. Conf. CA, Univ. California. :43-49.

do Carmo Teixeira, D., J. Luc Danet, S. Eveillard, E. Cristina Martins, W. Cintra de Jesus Junior, P. Takao Yamamoto, S. Aparecido Lopes, R. Beozzo Bassanezi, A. Juliano Ayres, C. Saillard, and J. M. Bové (2005). Citrus huanglongbing in São Paulo State, Brazil: PCR detection of the 'Candidatus' Liberibacter species associated with the disease. Mol. Cell. Probes. 19:173-179.

Coletta-Filho, H. D., M. L. P. N. Targon, M. A. Takita, J. D. De Negri, J. Pompeu, M. A. Machado, A. M. do Amaral, and G. W.Muller (2004). First report of the causal agent of huanglongbing (Candidatus Liberibacter asiaticus) in Brazil. Plant Dis. 88:1382-1382.

Folimonova, S. Y., C. J. Robertson, S. M. Garnsey, S. Gowda, and W. O. Dawson,. (2009). Examination of the responses of different genotypes of citrus to Huanglongbing (citrus greening) under different conditions. Phytopathology. 99:1346-1354.

Garnier, M., J. M. Bové, C. P. R. Cronje, G. M. Sanders, L. Korsten, and H. F. Le. Roux (2000). Presence of "Candidatus Liberibacter africanus " in the western cape province of South Africa. Fourteenth IOCV Conference, 2000-Short Communications

Gottwald, T. R., J. V. da Graça, and R. B. Bassanezi, (2007). Citrus Huanglongbing: The pathogen and its impact. Plant Heal. Prog. 8:31.

Grafton-Cardwell, E. E., K. E. Godfrey, M. E. Rogers, C. C. Childers, and P. A. Stansly (2006). Asian citrus psyllid. Oakl. Univ. Calif. Div. Agric. Nat. Resour. Pub. 8205. 
Halbert, S. E., and K. L. Manjunath (2004). Asian citrus psyllids ( Sternorrhyncha: Psyllidae ) and greening disease of citrus: A literature review and risk assessment in Florida. Florida Entomol. 87:330-353.

Jagoueix, S., J.-M. Bove, and M. Garnier (1994). The phloem-limited bacterium of greening disease of citrus is a member of the subdivision of the proteobacteria. Int. J. Syst. Bacteriol. 44:379-386.

Li, W., J. S. Hartung, and L. Levy (2006). Quantitative real-time PCR for detection and identification of Candidatus Liberibacter species associated with citrus huanglongbing. J. Microbiol. Methods. 66:104-115.

Mann, R. S., J. G. Ali, S. L. Hermann, S. Tiwari, K. S. Pelz-Stelinski, H. T. Alborn, and L. L. Stelinski (2012). Induced release of a plant-defense volatile "deceptively" attracts insect vectors to plants infected with a bacterial pathogen. PLoS Pathog. 8:e1002610.

McClean, A. P. D., and P. C. J. Oberholzer (1965). Citrus psylla, a vector of the greening disease of Sweet Orange. South African J. Agric. Sci. 8:297298.

McClean, A. P. D., and R. E. Schwarz (1970). Greening or blotchy-mottle disease of citrus. Phytophylactica. 2:177-194.

Miyakawa, T. (1980). Experimentally-induced symptoms and host range of citrus likubin (greening disease). Japanese J. Phytopathol. 46:224-230.

Spann, T. M., R. A. Atwood, J. D. Yates, M. E. Rogers, and R. H. Brlansky (2010). Dooryard citrus production : Citrus Greening Disease 1. :1-8.

Stover, E., S. Inch, M. L. Richardson, and D. G. Hall (2016). Conventional citrus of some scion/rootstock combinations show field tolerance under high huanglongbing disease pressure. HortScience. 51:127-132.

Stover, E., G. T. McCollum, R. Driggers, R. Lee, R. Shatters, Y. P. Duan, M. Ritenour, J. X. Chaparro, and D. G. Hall (2015). Resistance and tolerance to huanglongbing in citrus. Acta Hortic. 1065:899-904. 


\section{تقييم التحمل لمرض الاخضرار فى عشائر الموالح المرباة

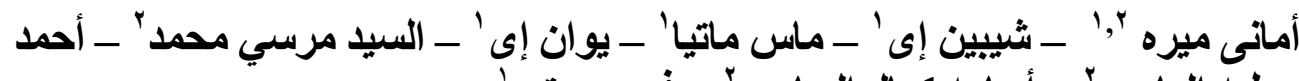

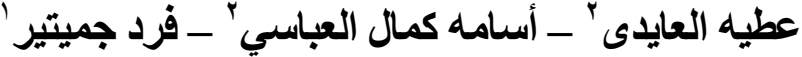

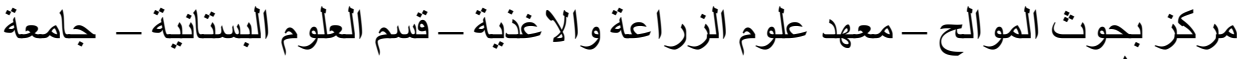

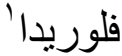 قسم البساتين - كلية الزر اعة - جامعة طنطا' ـ طنطا ـ مصر}

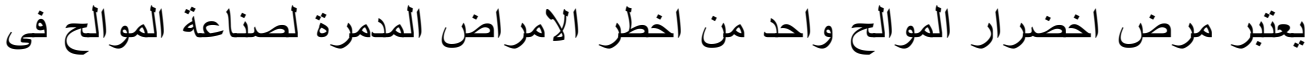

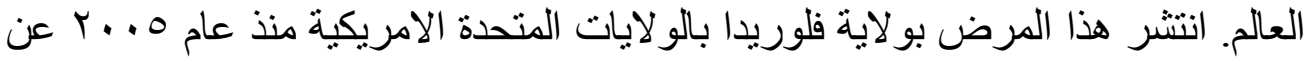

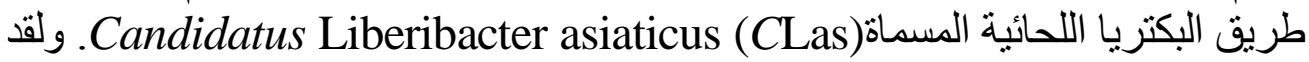

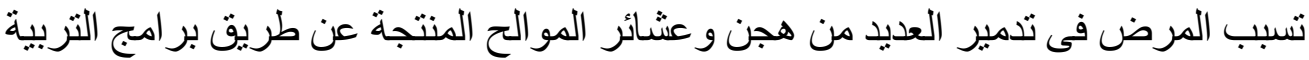

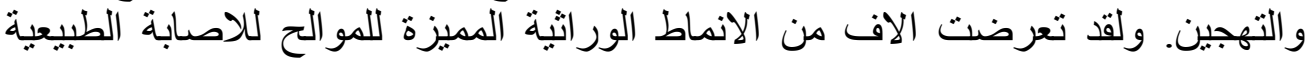

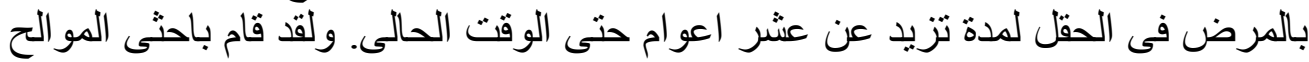

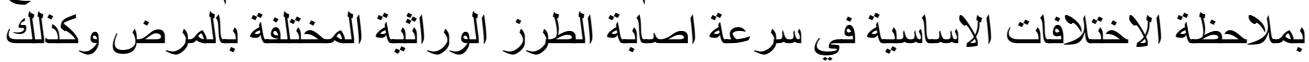

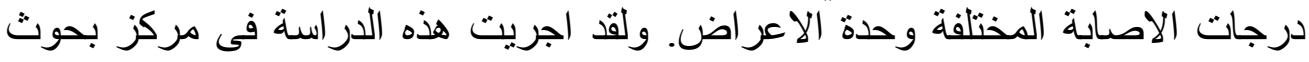

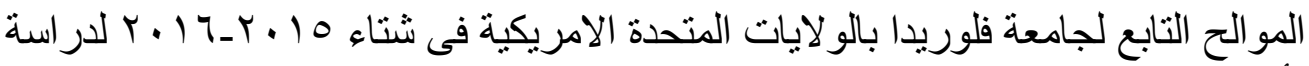

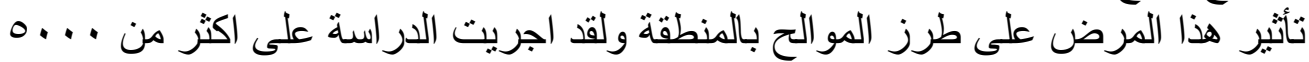

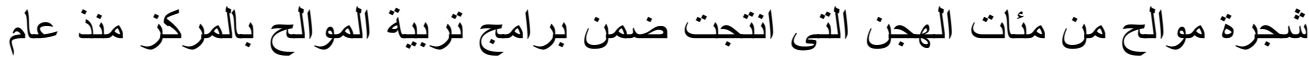

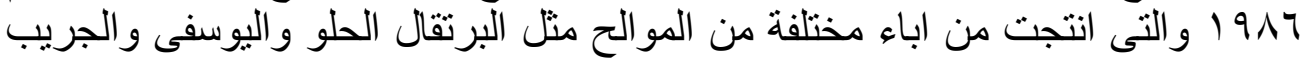

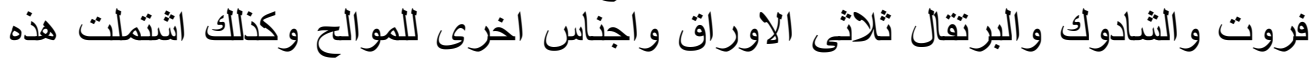

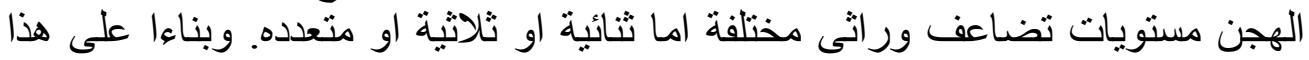

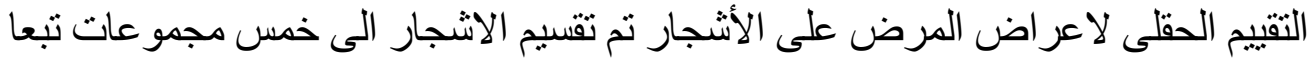

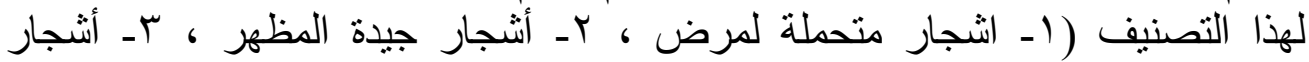

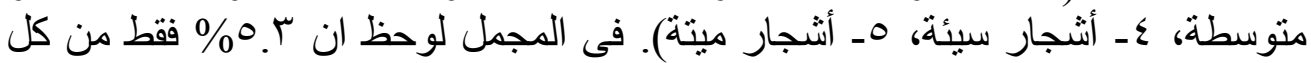

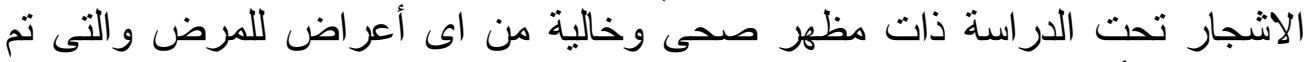

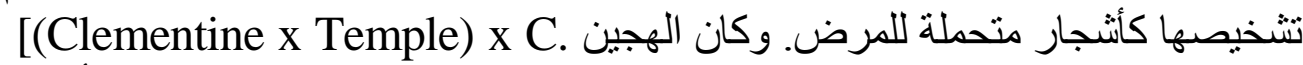
iمتبو عا بالهجين [Clemangensis]

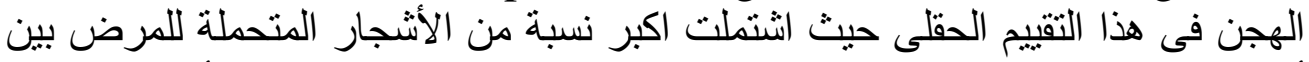

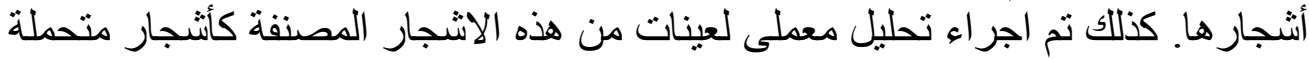

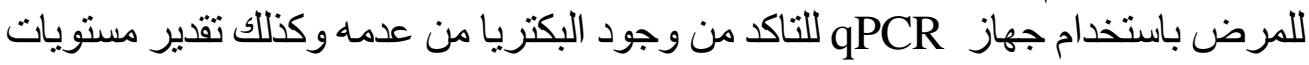




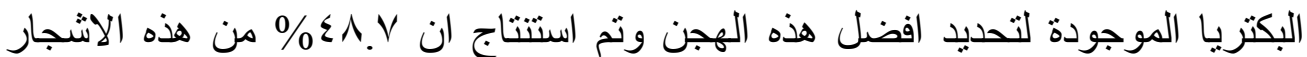

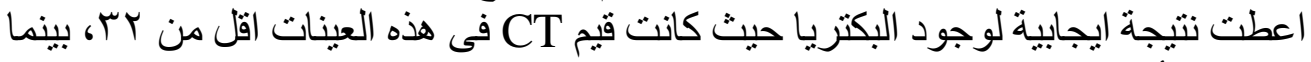

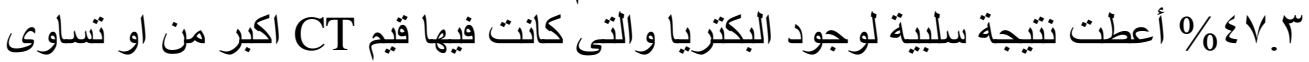

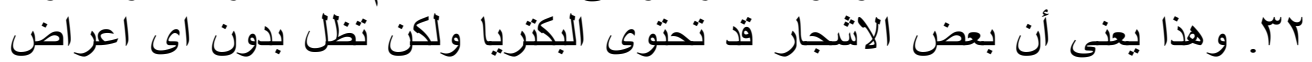

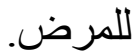

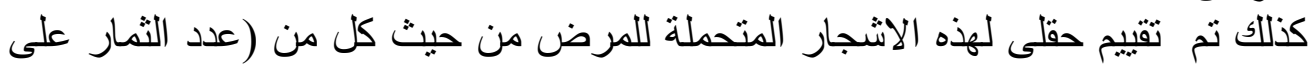

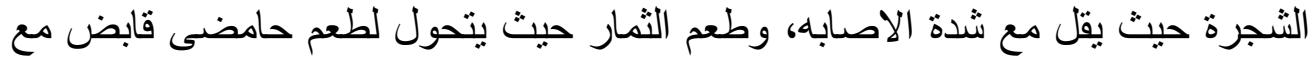

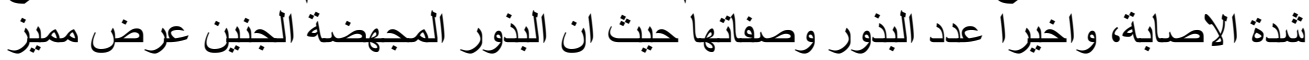

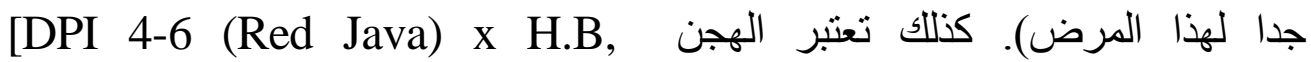
(Clementine X Minneola) x Chinotto, VB Temple x (Nova + (Nova + Succari), (Clementine $x \quad$ Ortanique), VB Temple $x$ هي أفضل الهجن حيث كانت قيم CTemple) X c. ichangensis

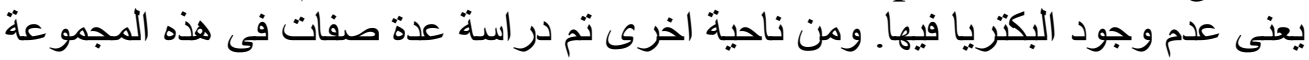

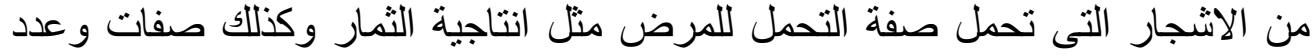

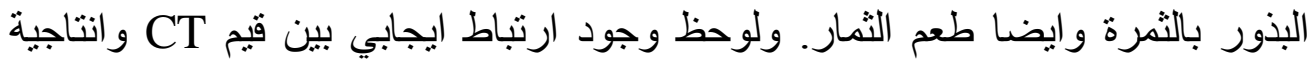

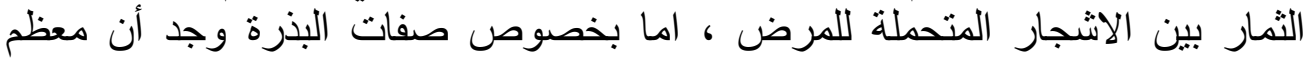

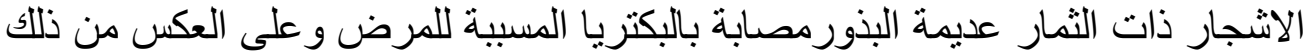

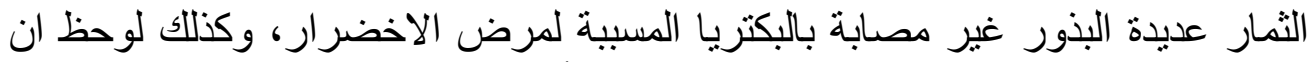

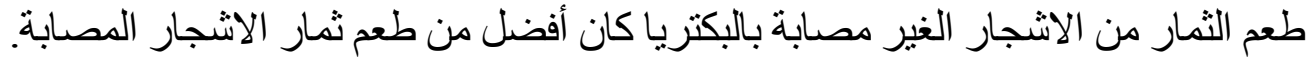

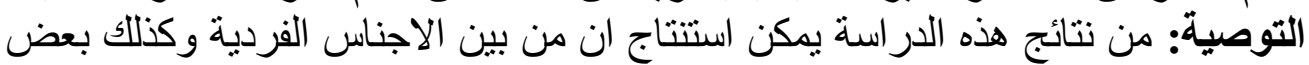

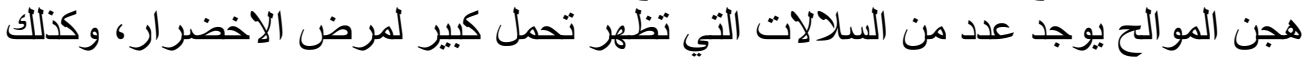

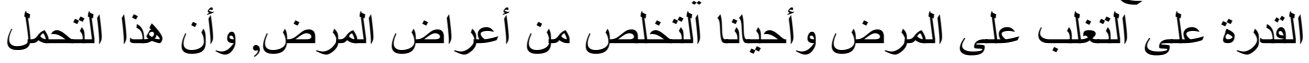

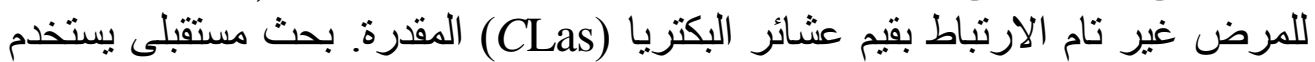
نتائج هذه الدراسة في تنفيذ الانتخاب الور اثنى فيى عشائر الموالح. 